\title{
Recovery of Municipal Solid Waste Recyclables under Different Incentive Schemes in Tamale, Ghana
}

\author{
Wilhemina Asare 1,2,*®D, Sampson Oduro Kwarteng 1,3, Emmanuel A. Donkor 1,3 \\ and Mizpah A.D. Rockson 4 (D) \\ 1 Regional Water and Environmental Sanitation Centre, Kwame Nkrumah University of Science and \\ Technology, Kumasi 00000, Ghana; Soduro-kwarteng.coe@knust.edu.gh (S.O.K.); \\ eadonkor.soe@knust.edu.gh (E.A.D.) \\ 2 Department of Ecotourism and Environmental Management, University for Development Studies, \\ Tamale Box TL 1350, Ghana \\ 3 Department of Civil Engineering, Kwame Nkrumah University of Science and Technology, Kumasi 00000, \\ Ghana \\ 4 Department of Chemical Engineering, Kwame Nkrumah University of Science and Technology, \\ Kumasi 00000, Ghana; madrockson.coe@knust.edu.gh \\ * Correspondence: ewilhemina@yahoo.com or wilhemina.asare@uds.edu.gh; Tel.: +233(0)-243-146-427
}

Received: 15 October 2020; Accepted: 20 November 2020; Published: 25 November 2020

\begin{abstract}
The recovery of recyclables from the waste stream is a vital factor to consider in any recycling scheme since it enhances the quality of recyclables and ensures efficient recycling schemes. This study was conducted in the Tamale Metropolis of Ghana to investigate incentive options that can promote municipal solid waste resource recovery to support policy decisions on the formalization of recycling scheme in the Metropolis. Solid waste source separation scheme was set up in four different waste management service zones in the Metropolis. The quantity of separated materials, set-out rate, as well as separation efficiency of the targeted materials in the scheme were also assessed. The result of the study indicated a high recovery factor for dry recyclables (53.97\%) as against food waste $(10.03 \%)$. There was a significant effect of incentives on waste material quantities. Significant differences also occurred in the set-out rates and separation efficiency. Moreover, the study showed that employing prize as a reward scheme in addition to the provision of a waste storage facility had a high propensity for waste material recovery. The study demonstrated that the quantity of waste materials that may be retrieved in a recycling scheme in different solid waste management service zones depends on the type of incentive employed in the scheme and the service zone considered.
\end{abstract}

Keywords: recovery; municipal solid waste; resource; options; incentives; recyclables

\section{Introduction}

Source separation refers to the separation of household solid waste into different categories at source for further treatment [1]. On the other hand, resource recovery involves thorough separation of individual waste components by householders, commercial establishment, and industry of municipal institutions [2]. Source separation is seen as a viable method of reducing waste quantities and a key component in promoting recycling [3,4]. Studies have shown that it is better to separate recyclable materials at the source of generation than the separation of mixed waste at a material recovery facility, as cleaner and higher quality materials are produced through sorting at source [5]. Subsequently, the sorted materials are collected and stored in separate bins and transported to a facility for processing. The primary processed and clean materials can then be sold for reprocessing into other products by industries. It is argued that recycling produces one of the most realistic economic and ecologically 
sound solutions in managing solid waste disposal [6]. The key direct economic benefits of source separation programs are the earnings made from sales of the recovered waste materials and the credits for avoiding part of the cost of disposal by landfill or other means of disposal [7]. However, information on waste generation rate gives indication of waste quantities that can be generated to serve as a guide in projecting potential waste generation rate in a city [8] and to determine management strategies to be utilized [9].

According to Pichtel [2], analysis of waste types is one of the most immediate variables to be determined when considering the implementation of a new collection system for a community and it is achieved through waste characterization study. Waste characterization study is needed for realistic estimation of potential recyclables to aid decision making on solid waste treatment technologies $[9,10]$. It is believed that assessment of waste composition and available recyclable quantities facilitates well-organized and smooth functioning of recycling programs. Ultimately, this reduces the amount of waste generated, thereby reducing total waste management costs [11]. It also provides information on the use of materials for composting and conversion into various products such as compost and mulch, providing both a soil conditioner and a partial substitute for chemical fertilizer [12].

Hornik et al. [13], asserted that monetary rewards can catalyze desired recycling behavior, though limited by long-term sustainability. Conversely, extensive education can be used to overcome such limitations [14]. Incentives used in promoting recycling behavior could be in the form of reward or penalty. The penalty is considered in policy as economic tools instituted to improve certain behavioral target or cause a change in behavioral patterns, while rewards are any form of incentives given by competent authorities or government for improved recycling activities [15]. For example, provision of free containers, cash payment, voucher, and tax exemption, among others [15]. Reward schemes may also come in a form of prizes, bonuses, lotteries, tax exemptions, discounts, or waivers [16]. Some may also include the establishment of a product charge on recoverable waste materials that are disposed of, modification of the percentage depletion allowance, and the institution of governments' income tax credit for the purchase of recycled materials. These mechanisms can lead to an upsurge in the demand for recycled waste materials, encourage source separation, and consequently, promote a range of waste recycling activities [16].

Studies have shown that, in developing countries, both economic concerns and moral obligations influence recycling outcomes at the household level $[17,18]$. This assertion is supported by a coterie of studies (e.g., [19-22]). Several studies have discovered how incentives can support recycling and reduce waste disposal cost. For instance, an incentive-based source separation model piloted in Guiyang city in China yielded an increase in net benefit by 18.3 Chinese yuan (CNY) per ton after a year of operation [23]. The same study was able to achieve a $54.3 \%$ reduction in waste quantity which otherwise would have required financial resources at its disposal. Additionally, the study by [24] in Lahore in Pakistan, indicated that out of the total recyclable waste generated, $21.2 \%$ of the waste recycled through the informal sector generated 271 million rupees (Rs) per annum, equivalent to US $\$ 4.5$ million. This is an indication that local authorities have the advantage of making considerable savings from formalized recycling activities. Suttibak and Nitivattananon's [25] study in Thailand reported a satisfactory diversion rate and a good benefit-cost ratio. Due to the benefit of recycling, in [26] it is asserted that a viable means of promoting recycling behavior is to induce individuals to form a positive intention to perform the desired behavior. Guagnano et al. [27] also emphasized that recycling schemes without rewards and which are not mandatory would have a difficulty in promoting recycling behaviour. This may particularly be the case when cheap/free disposal of waste is available to the people, which creates a little economic incentive for them to recycle or to reduce their waste. Matter et al. [28] suggested the use of economic incentives by governments, municipal, and district authorities, as well as waste management institutions to encourage waste recycling.

The incentives proposition is also supported by several scholarly studies $[1,14,15,29-33]$. Studies have also shown that, in general, incentives and rewards are preferred over penalties for waste recovery $[15,31,34]$. However, due to the inadequate amount of empirically evaluated incentive 
schemes, it is hard to name one preferred incentive form over another and more especially in different municipal solid waste (MSW) service areas. Survey-based results tend to reveal that households prefer community-based rewards [31]. On the other hand, results based on actual pilot scheme projects disclosed that incentives and rewards given out based on the performance of a group of households did not lead to significant changes in the collective behavior of the households [35].

Similarly, other scholars have argued for the imperativeness of establishing a convenient location of recycling points such as drop-off centers $[12,36]$ to facilitate residents' participation in recycling schemes. In support of this, Oduro-Kwarteng et al. [14] affirmed incentive schemes by proposing the provision of options as a necessary factor for safeguarding source separation programmes. Extensive studies on recycling have also indicated households' preference of both monetary and non-monetary incentives as motivation $[14,30,32,37,38]$.

The issues of waste management in Ghana, as well as the Tamale Metropolis, are not different from the general perspectives drawn from studies in other jurisdictions. However, in the Tamale Metropolis, the informal sector is actively involved in recyclables trading and is operating in almost all the communities in the Metropolis. Moreover, there is no formalized recycling program in place; mixed wastes are transported to landfill for disposal together with materials which can be recycled to serve as a plough-back venture for its management. In addition, the majority of people depend on free disposal at the communal skips positioned at vantage points in the communities which creates little or no incentives for them to recycle their waste. Only residents in door-to-door service zones, usually located in high- and middle-income areas, who subscribe to door-to-door waste collection services, pay an amount of Gh $\$ 30$ for door-to-door collection of their waste. The delays in disbursement of funds to the Metropolitan Assemblies by the central government coupled with low user-fee turnovers makes it difficult for waste management authorities and contractors to invest in new facilities and treatment technologies to support waste resources recovery. This is because waste management is mainly financed by the central government. These and many other factors have made the Metropolitan Assembly incapable of rendering effective waste management services in all the areas in the Metropolis. Alternatively, formalized recycling schemes may support waste diversion from the landfill and reduce the financial resources needed for the management of the waste.

So far, no attempt has been made by the city authority to implement any form of formalized recycling program, despite the activeness of the informal sectors in recycling in the metropolis. From the mixed disposal system utilized in the Tamale Metropolitan area, it can be concluded with certainty that there is an apparent lack of knowledge on recycling on the part of the public and lack of action by authorities to implement MSW sorting and recycling programs. Existing literature underscores the role of economic incentive in enhancing recycling and producing economic gains for city authorities and the inhabitants (e.g., [23-25,30]). It is, therefore, no gainsaying that it is prudent to institute recycling programs that provide economic benefits to recyclers to promote participation and increase recyclables yield to reduce the quantities of waste that goes to the landfill.

It is significant to note that achieving the objectives of recycling programs is contingent upon the availability of accurate information on the recovery rate of various materials and the influence of incentives on recyclable yield. Literature exists on recycling in Ghana, but the literature focused essentially on human cognizance and few have concentrated on an empirical analysis $[9,14,29,37]$. However, there is a lacuna in intellectual discourse on recycling in Ghana as the existing studies did not focus on the influence of incentive options on recyclable yields. It is an incontrovertible fact that recyclable types and quantities are a necessary factor for the selection of treatment and management options and efficient recycling schemes $[9,10,39]$. Therefore, incentives are too crucial to be ignored in recycling programs. The question then is: which combination of incentive and service zone will give a realistic quantity of recyclables to support a recycling scheme?

The study sought to (1) investigate the influence of incentives options on waste materials recovery to promote household participation and retrieval of sorted solid waste fractions from household waste to support formalize the recycling scheme in the Tamale Metropolis. Additionally, the study aimed 
to (2) provide city authorities and industry with science-based evidence on the best combination of incentives and service zones that drives positive recycling behavior and increases waste recyclables yield to assist waste contractors and city authorities to shift the solid waste management strategies to focus more on recyclable materials resources recovery to increase waste diversion from the landfill and reduce the management cost.

\section{Materials and Methods}

\subsection{Study Area}

The study was conducted in the Tamale Metropolis in the Northern Region of Ghana and included some communities under Sagnarigu district because of the joint solid waste management for the two areas. The Metropolis is considered one of the fastest growing cities in Ghana, with an annual population growth rate of $3.5 \%$, and it lies between latitude $9^{\circ} 16^{\prime}$ and $9^{\circ} 34^{\prime}$ North and longitudes $0^{\circ} 36^{\prime}$ and $0^{\circ} 57^{\prime}$ West. Based on the 2010 population and housing census, the areas were projected to have a population of 485,000 in the year 2017 and about 69,286 housing units with $80.8 \%$ of its inhabitants dwelling in the urbanized areas, influencing waste generation in the city [40].

Waste disposal methods used in the areas are mainly two, a door-to-door and communal collection using skip containers. The study focused more on the urbanized areas in the metropolis due to the availability of waste management services in these areas. Figure 1 depicts the map of the study areas and selected households for the study.

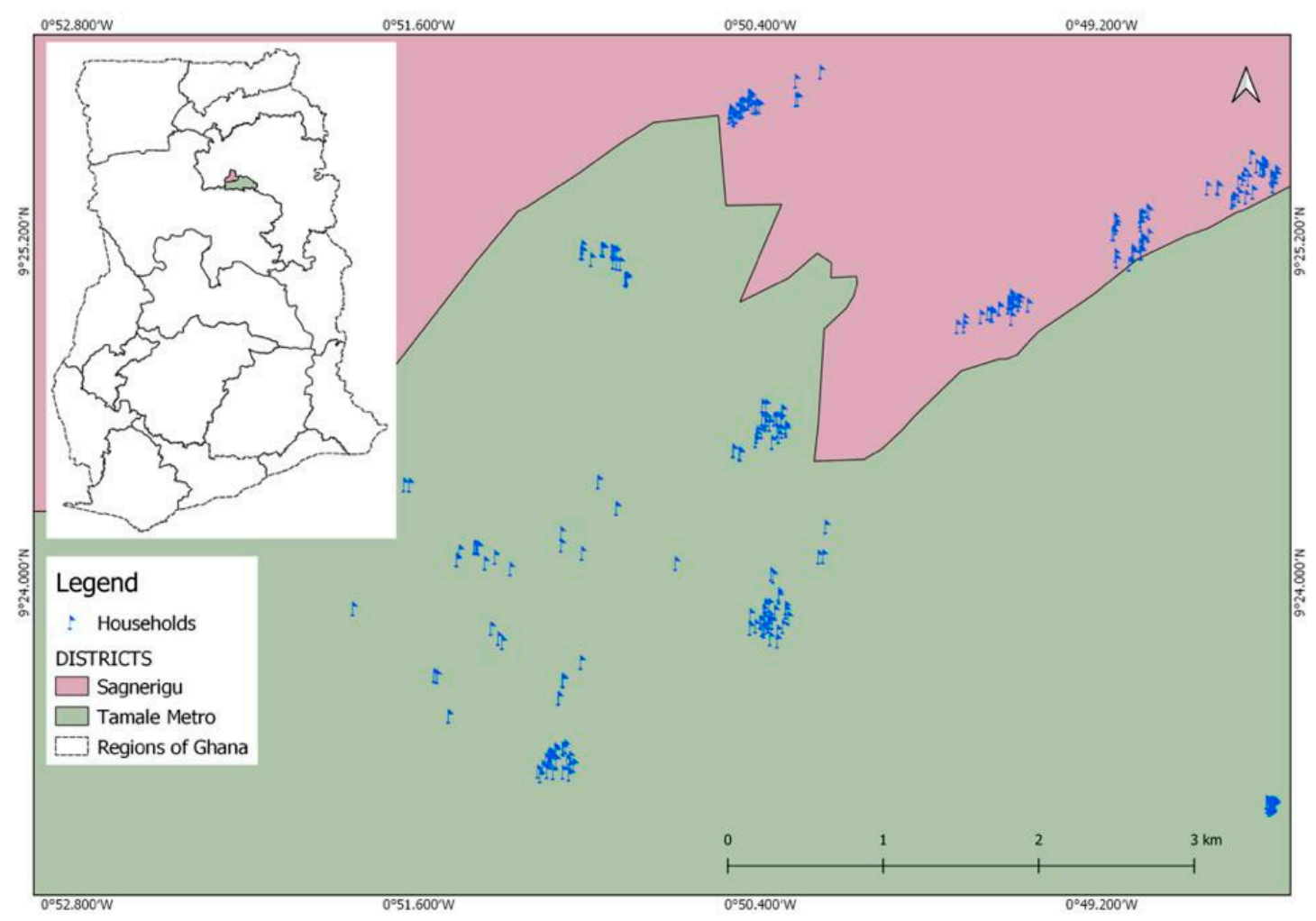

Figure 1. Map of study areas showing sampled household (authors' own construction).

\subsection{Data Collection}

\section{Waste Characterization Study and Analysis of Waste Material Resources Recovery}

Twelve weeks' municipal solid waste source separation and separate collection schemes were piloted in twelve communities in three different income residential classes under two major waste collection schemes (door-to-door and communal) under four solid waste management service zones. 
The required sample size for the waste characterization analysis was calculated using the formula developed by [41] and following other studies in $[29,42,43]$. The formula is

$$
n=Z * Z[P * P) /(D * D)]
$$

where $n=$ the sample size, $Z=$ value for a selected alpha level of each tail $=1.96 ; P=$ estimated population standard deviation based on a pre-study, and $D=$ acceptable margin of error (0.05). From the calculation, a total of $8074.7 \mathrm{~kg}$ of waste was to be used for the waste characterizations study, however, all the primary sorted waste from the household was used for the characterization which was more than the estimated quantity.

A total of 360 households were randomly selected for the study, which comprises thirty (30) households selected in three randomly selected communities in each of the four different service zones. Each community was given one incentive option as treatment and each treatment replication for thirty households for twelve (12) weeks. Three incentive options were given to households; $1=$ only waste storage facility (waste bins and sacks), $2=$ a prize of $\mathrm{GH} ₫ 2.5$ per week in addition to a waste storage facility, and $3=$ a $30 \%$ bonus on recyclables in addition to a storage facility.

Waste bins were provided in door-to-door service zones and sacks in communal services zones as storage facilities; this was done due to the availability of space for storage facilities in the service areas. For simplification and easy discussion of results, incentive options two and three are stated as prize and bonus. Stratified, purposive, and random sampling technique was employed to select zones, communities, and the number of households. The study employed two main collection modes, namely, door-to-door and communal collection at communal waste collection points in the communities. The number of households randomly selected in the service zone and incentives employed in the study are shown in Table 1.

Table 1. Number of selected communities and sampled households.

\begin{tabular}{|c|c|c|c|c|}
\hline Community & Residential Class & Incentive Option & Mode of Collection & Sample Size $(N=360)$ \\
\hline \multicolumn{5}{|c|}{ High-income door-to-door (HI DtD) } \\
\hline 1 & High-income Area & Waste receptacles & Door to Door & 30 \\
\hline 2 & High-income Area & Prize & Door to Door & 30 \\
\hline 3 & High-income Area & Bonus & Door to Door & 30 \\
\hline Total & & & & 90 \\
\hline \multicolumn{5}{|c|}{ Middle-income door-to-door (MI DtD) } \\
\hline 1 & Middle-income Area & Waste receptacles & Door to Door & 30 \\
\hline 2 & Middle-income Area & Prize & Door to Door & 30 \\
\hline 3 & Middle-income Area & Bonus & Door to Door & 30 \\
\hline Total & & & & 90 \\
\hline \multicolumn{5}{|c|}{ Middle-income communal (MIC) } \\
\hline 1 & Middle-income Area & Waste receptacles & Communal (drop-off) & 30 \\
\hline 2 & Middle-income Area & Prize & Communal (drop-off) & 30 \\
\hline 3 & Middle-income Area & Bonus & Communal (drop-off) & 30 \\
\hline Total & & & & 90 \\
\hline \multicolumn{5}{|c|}{ Low-income communal (LIC) } \\
\hline 1 & Low-income Area & Waste receptacles & Communal (drop-off) & 30 \\
\hline 2 & Low-income Area & Prize & Communal (drop-off) & 30 \\
\hline 3 & Low-income Area & Bonus & Communal (drop-off) & 30 \\
\hline Total & & & & 90 \\
\hline
\end{tabular}

Households selected for the study were given prior information on the program through personal contacts and the use of leaflets. A brochure was distributed to the households accompanied by two labelled sacks or waste bins lined with black polythene bags. Sack 1/black bin for food wastes (food leftover, fruits, peels, vegetables) and sack 2/ash bin for dry recyclables (plastics-Polyethylene Terephthalate (PET), High Density Polyethylene (HDPE), Low Density Polyethylene (LDPE) and 
Polypropylene (PP), and other plastics, paper-mixed paper and cardboards, glass—clear and colored glass and metals scraps and aluminum cans). The house numbers of selected households and items to be placed in each sack/bin were inscribed on the body of the sacks/bins and polythene bags. The polythene bags and sacks were replaced when worn out.

The primary sorted dry recyclables waste was collected twice a week and the food waste collected daily for 12 weeks in each service zone. The content of each labelled bag was emptied for sorting and weighing on each collection day. The direct sampling method was employed, whereby materials were manually sorted into various components $[9,11,29,37,44]$. The components realized were quantified in grams using a weighing scale. The dry recyclables were sorted into four major classes, plastics, metals, paper, and glass. The materials under the major groups discussed in this paper are materials with recycling values.

The parameters below were estimated to determine the recovery rate under each incentive scheme. The quantity of materials produced per household $(\mathrm{WH})=\frac{T Q M}{T H} \times S D$ where $T Q M$ is the total quantity of sorted waste per household, TH is the total households who participated in the study and SD is the study duration.

Percentage (\%) of each component was calculated as $\frac{Q i}{T Q W} \times 100$ where $Q i$ is the quantity of the material under consideration, $T Q W$ is the total waste quantity, all expressed as a percentage. The set-out rate ( $S$ in percentage) was calculated using the number of households that separated their waste into the designated bags $(B)$ and the total number of households $(H)$ who participated in the study using the formula shown below: $S=\frac{B}{H} \times 100$.

The percentage separation efficiency ( $\% S E$ ) was determined by measuring the percentage by weight of recovered fractions ( $R f$ in $g$ ) correctly placed in each bag and the total weight of waste in the bag $(W T$ in $g) ; \% S E=\frac{R f}{W T} \times 100$ where $R f$ is the weight of sorted waste fraction, WT is the total weight of waste sorted. The recovery factor was calculated as recovery factor $=Q T M * S E$ where $T Q M=$ quantity of targeted material in the waste stream and $S E=$ separation efficiency [39].

\subsection{Data Analysis}

Data obtained on waste material quantities were analyzed using descriptive statistics in statistics/data analysis special edition (Stata version 14.0) and presented in Tables and Figures. Multivariate analysis of variance was carried out to determine the difference in waste quantities across service zones and incentives options. It was also employed to test differences in set-out and separation efficiency for waste materials resources across incentive options. Multivariate regression analysis was done to establish the effect of incentives on waste materials recovery.

\section{Results and Discussions}

\subsection{Composition of the Primary Sorted Waste Stream}

The waste segregation pilot study carried out for twelve weeks produced a total of 33,081.1 kg of primary sorted waste from a total of 360 households in the Tamale Metropolis in the Northern Region of Ghana. From the total waste produced by the households, the total waste materials that can be recycled or composted was $32,277 \mathrm{~kg}$, out of which $6862.8 \mathrm{~kg}$ were food waste and $18,594.5 \mathrm{~kg}$ were dry recyclables waste materials. The results obtained in the study agrees with that reported elsewhere in other parts of the world, as the solid waste segregated in low-income countries was about $2217.2 \mathrm{~kg}$ [45]. Additionally, Alias et al. [46] found $1519.3 \mathrm{~kg}$ of separated solid waste in Sabah, Malaysia. The result of the study showed that the primary sorted waste is composed of paper, glass, metals, plastics, food, miscellaneous, and household hazardous waste. The compositional analysis of the waste samples indicates that there is a marked higher generation of plastics and food waste in the study area; $42.96 \%$ and $25.68 \%$, respectively. The large quantities of plastics and food waste may be as a result of the influence of economic class and household dynamics on solid waste generation and composition $[47,48]$. Additionally, the large quantities of plastic waste materials 
retrieved in the scheme could be attributed to limited alternative re-use options and inadequate recycling systems in the metropolis.

Paper and glass had the lowest percentages in the primary sorted waste stream from this study, thus, $3.80 \%$ and $4.43 \%$,respectively, while non-targeted material (hazardous waste and miscellaneous) were $0.03 \%$ and $1.18 \%$, respectively, in the waste stream (Figure 2). This was in line with findings in Kumasi, Ghana shown in [8], where a lower percentage of glass (1.1\%) was retrieved from the waste stream. However, the finding contradicts that of [49] in Beijing who reported a higher percentage of paper $(10.7 \%)$ in their study. The findings of this study are similar to those of the study in Putra, Malaysia in [50], which found sorted waste organics to be $55 \%$, plastics $(30 \%)$, paper $(11 \%)$, glass $(1 \%)$, and metal $(2 \%)$ in the waste stream. The waste materials that had a high recovery rate could serve as the basic materials to focus on in the recycling scheme to support continuous materials flow for recycling purposes. Yang et al. [49] reported a higher potential recycling value for plastics and food waste compared to other waste components in the waste stream. These materials could present a viable economic venture to support the country's economy if they are properly valued.

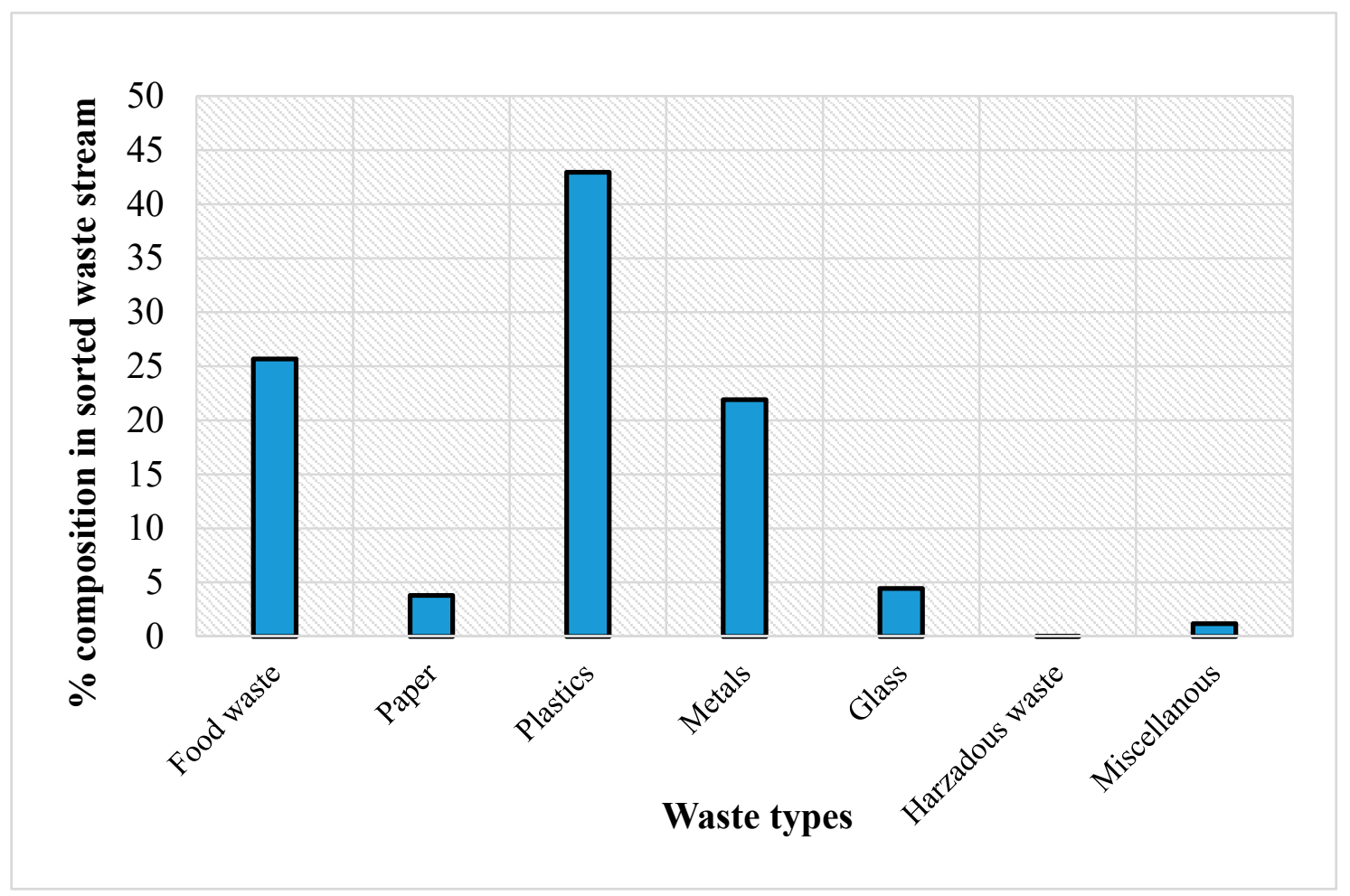

Figure 2. Composition of the sorted waste stream.

\subsection{Average Recyclables and Food Waste Materials Retrieved for the Study Period}

The result on average waste resources retrieved for the study period indicated that dry recyclables had the highest mean quantity of $4552.44 \mathrm{~g}$ per household for the study period as compared to food waste $(1761.85 \mathrm{~g})$. The average total of recyclables and food waste produced was $6314.282 \mathrm{~g}$ per household for the study period.

In terms of dry recyclables' components, plastics had the highest mean quantity of $2513.35 \mathrm{~g}$ per household for the study period. This was followed by metals (1395.38 g) and the smallest amounts of $215.70 \mathrm{~g}$ and $427.98 \mathrm{~g}$ were for paper and glass, respectively. However, the retrieval of paper was relatively lower than that of glass as indicated in Figure 3. A study of municipal solid waste in the Balkan region reported the organic fraction of waste in Bulgaria and Romania to be $58.3 \%$ and $59.2 \%$, respectively [51]. Several other studies have demonstrated that the amount of organic waste often comprises more than $50 \%$ of the total generated solid waste in developing countries [52-54]. 
The findings of the study contradict that of $[29,37]$ study in Ghana and $[3,49]$ studies in Beijing and Palestine which reported high organic waste contents in the waste stream. On the other hand, the findings are in tandem with the findings of $[37,55]$ in Ghana that established a lower percentage of glass (1.1\%) in the waste stream. The finding again contradicts that of the study in [49] regarding Beijing in which higher percentage of paper $(10.7 \%)$ was reported. However, waste generation is known to be influenced by several factors such as geographical location, income, household size, time, among others $[9,37,39]$, and this may have accounted for variation in the results.

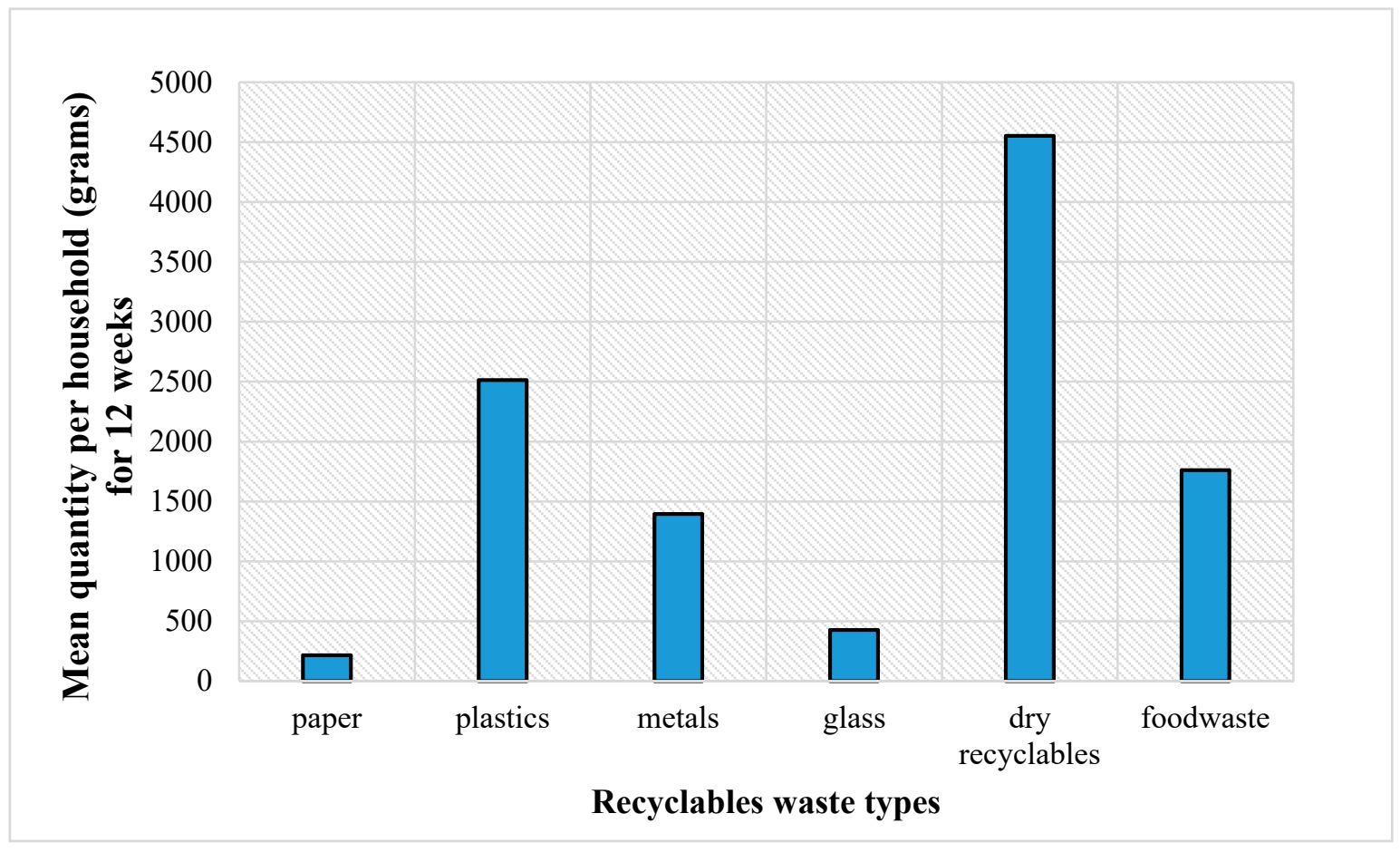

Figure 3. Average recyclables and food waste retrieved for the study period.

Again, food waste is just a fraction of organic waste, so other organic waste components may have contributed to the higher content of organic waste fractions reported by other studies. However, the quantity of materials separated for the recycling scheme seems to differ from what can be retrieved from normal waste composition analysis. A similar observation was made in [6] where differences were reported in the composition of the pre-recycling waste stream across three districts in New York and post-collection recovery efforts were recommended to augment residents' recycling efforts, after noticing that the discarded waste stream may contain appreciable quantities of recyclables materials.

\subsection{Recyclables and Food Waste Materials Resources Retrieved from the Incentives Options}

According to the result of the study, the incentive option prize produced the highest dry recyclable $(5613.52 \mathrm{~g})$ and food waste $(2182.57 \mathrm{~g})$ materials per household for the study period. The incentive options-waste receptacles and bonus produced more dry recyclables waste materials thus, $4454.18 \mathrm{~g}$ and $3589.608 \mathrm{~g}$ compared to food waste material thus, $1544.609 \mathrm{~g}$ and $1558.67 \mathrm{~g}$ per household, respectively. In terms of dry recyclable components, the largest quantity of plastics was produced by waste receptacle $(2787.29 \mathrm{~g})$ followed by prize $(2636.63 \mathrm{~g})$ and the smallest quantity from bonus, thus, $2116.21 \mathrm{~g}$ per household. On the other hand, prize recorded the largest quantity of metals (2121.19 g), followed by waste receptacles $(1235.73 \mathrm{~g}$ ), while bonus recorded the smallest quantity of $829.2 \mathrm{~g}$ of metals per households. The highest quantity of paper was produced by prize ( $383.01 \mathrm{~g})$, followed by waste receptacle $(199.35 \mathrm{~g}$ ) and bonus which produced $64.73 \mathrm{~g}$ of paper materials per household. 
The quantity of glass separated per household for the study period was higher for bonus, namely, $579.47 \mathrm{~g}$, compared to prize (472.66 g) and waste receptacles $(231.82 \mathrm{~g})$, as indicated in Figure 4 below. This result agrees with the findings of [56] which found that financial incentives can promote pro-environmental behavior and contribute to sustained behavior. Likewise, the minor role is that financial incentive is a tangible benefit for recycling. This finding infers that the role of incentives is crucial to the sustainability of recycling of municipal solid waste. Thus, the unveiling of incentives such as prize for the recycling of municipal solid waste is required for furthering household participation in the recycling of municipal solid waste.

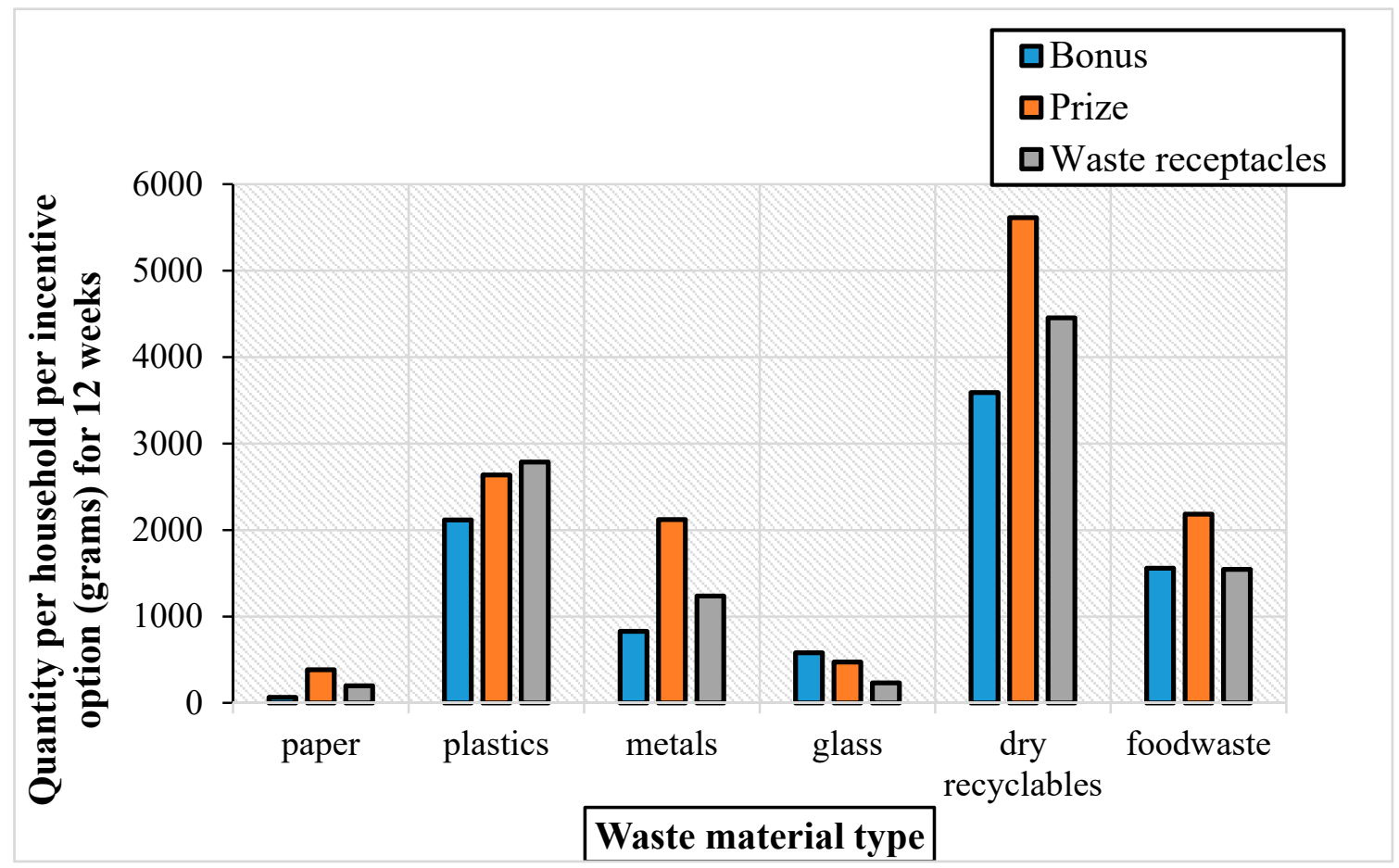

Figure 4. Average recyclable waste materials from the incentive options.

The mean recovery of waste materials per incentive options gives an idea as to which incentives to focus on in terms of targeted material in a recycling scheme to achieve realistic quantities of materials to support materials flow in a recycling scheme. It also provides information on the amount of material that can be retrieved in time to support recycling schemes. The finding of the study is also similar to a study conducted by [57] in Thailand which indicated difference in food waste quantities produced by communities and observed higher food waste quantities produced by a reward scheme than the traditional system without incentive. The variations in waste quantities retrieved across incentive options and service zones could be attributed to the differences in income levels since the service zones used in the study belong to different income levels groups. This is consistent with studies by [3] and [58] who reported differences in waste composition across income levels.

\subsection{Recyclables Waste Materials Resources from Incentives Options Across the Service Zones}

The result of the study indicated in Figure 5 below shows the quantities of separated materials per incentive options in the service zones. Among the incentive options, waste receptacles had the largest quantities of separated dry recyclables material $(2952.98 \mathrm{~g})$ and plastics materials (1722.92 g) per household for the study period in the high-income door-to-door service zone. However, the largest quantities of food waste $(2849.17 \mathrm{~g})$ were produced by prize, followed by waste receptacles $(1887.20 \mathrm{~g})$ in the high-income service zone. Prize again produced the largest quantity of food waste (1824.43 g), while bonus produced the largest quantity of dry recyclables (3411.33 g) in the middle-income 
door-to-door service zone. The incentive option waste receptacles followed second in terms of dry recyclables quantities $(2000.29 \mathrm{~g})$ and food waste $(690.18 \mathrm{~g})$ retrieval in this zone. Plastic quantities were relatively high across all incentive options compared to the other waste material types but had a high recovery under the incentive option bonus which produced $2264.33 \mathrm{~g}$ of plastic materials per household for the study period in this service zone.

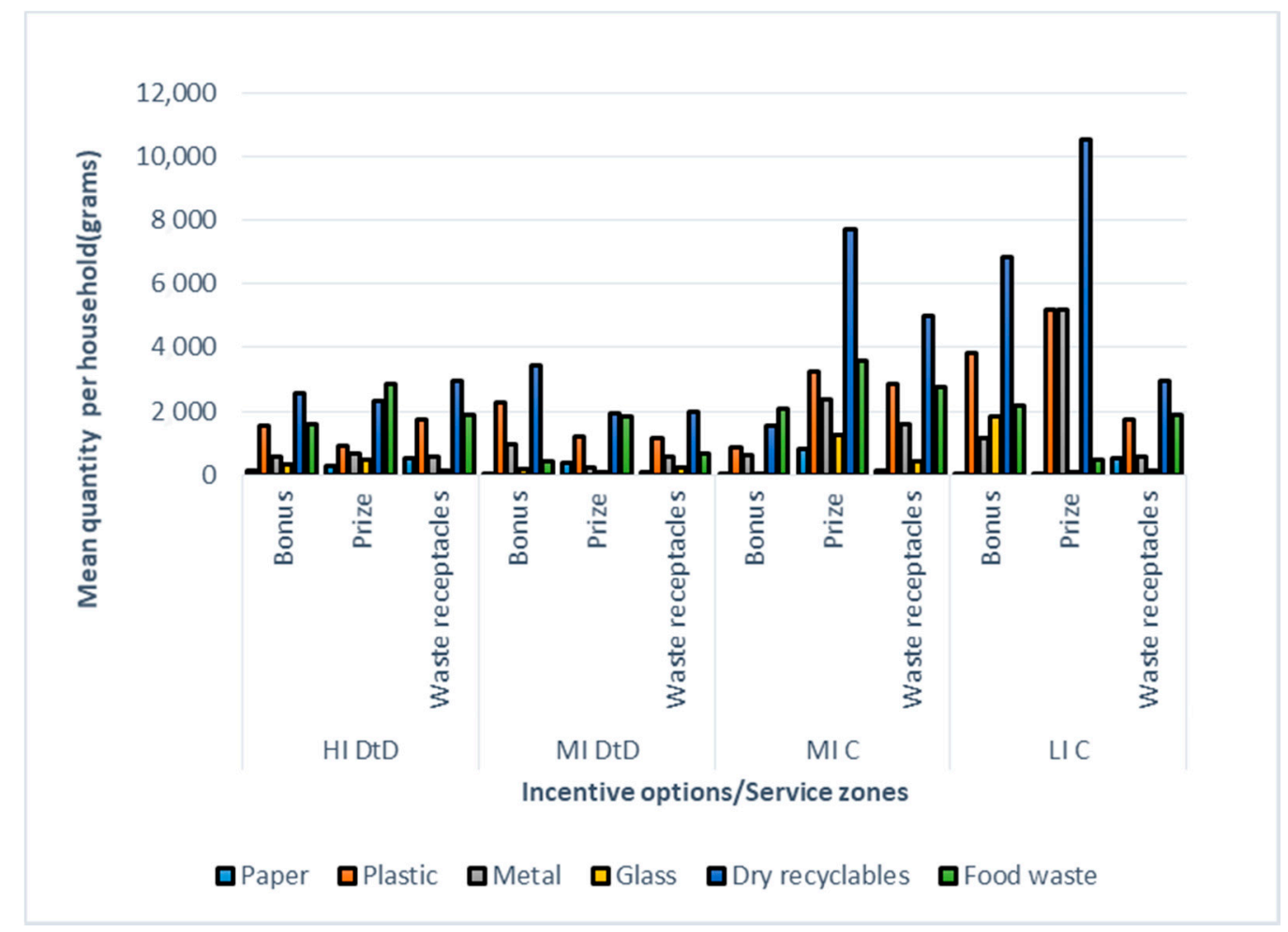

Figure 5. Recyclable waste materials per incentive option across service zones.

In the middle-income communal service zone, prize recorded the highest quantities of both dry recyclables (7709.17 g) and food waste (3588.33 g) as well as plastics (3262.5 g) and metals (2386.67 g) per household for the study period. Waste receptacles followed second after prize in the quantities of the above mentioned materials (Figure 5). Conversely, prize produced high quantities of glass (1226.7g) for the zone compared to the other incentive options. In the low-income service zone, the largest quantities of dry recyclables $(6823.3 \mathrm{~g})$, metals $(5201.95 \mathrm{~g})$, and plastics (5183.61 g) were produced by prize, while the largest quantity of food waste was produced by bonus $(2155.28 \mathrm{~g})$. However, bonus produced the highest quantities of sorted glass $(1810.28 \mathrm{~g})$ in the zone. Large plastics quantities were realized for all incentive options in this zone, but the highest plastic waste quantity (5183.61 g) per household for the study period was realized by the incentive option prize in this service zone.

The study showed variations in quantities of materials retrieved under incentives across service zones based on the mean values. The study revealed high performance among all the incentive options across the communal service zones for the recovery of the waste materials compared to the door-to-door zones. This could be attributed to the quest for economic benefit from recycling among recyclers in the communal service zones compared to those in the door-to-door zone. The economic incentive which accompanied the scheme may have increased households' recycling performance in these zones. The findings of the study are in line with the studies by [16-18] which reported economic incentives as a drive for positive recycling behavior among households.

The result is also consistent with a study by [57] who reported increase in separated food waste under reward scheme than the voluntary and traditional scheme in Thailand. The performance 
in the communal zone may also be attributed to the convenient location of drop-off centres. This agrees with the study in England by [59] which stated that having access to convenient collection infrastructure seems to be one of the most, if not the most important factor influencing household's motivation to participate in recycling. The different quantities of food waste produced by the service zones and incentives contradict the studies in $[3,58]$ whose findings established an inverse relationship between the amount of organic waste and economic development. With this report, it was anticipated that the door-to-door areas which are considered more elite and of good economic standings, would produce less food waste but the opposite was seen in this study. This could be attributed to the fact that residents in the high-income zone had no alternative uses for food waste as compared to those in the low-income zone who depend on food waste as feed sources for their domestic animals.

\subsection{Waste Material Recovery Rate under Incentives and Service Zones}

A well-developed collection scheme is not only a basic requirement for source separation but also the implementation of a reward scheme in particular [34]. Additionally, an increase in participation in a kerbside scheme could best be achieved through changes in the design of the collection scheme, such as the organization of the pick-up of household waste [31]. Woodard et al. [47] also found out that participation rates correlate positively with the number of separately collected materials. From the study, the recovery factor (R.F) which represents material recovery in the recycling scheme was computed for the targeted materials in grams under the different incentives options and services zones. Provision of waste receptacles registered the highest dry recyclables recovery in the low-income zone and also produced the highest food waste recovery in the high-income zone. On the other hand, the incentive option prize produced the highest food waste recovery $(29.08 \%)$ in the high-income zone, but the highest dry recyclables recovery occurred in the middle-income communal zone (36.28\%).

The highest food waste recovery for the incentive option bonus occurred in the middle-income communal zone and the least food waste recovery occurred in middle-income door-to-door zone for the incentive option bonus. Dry recyclable registered the highest R.F compared to food waste across all the incentives options (Table 2). However, the incentive option waste receptacles produced the greatest amount of dry recyclables R.F (29.92\%) compared to the incentive options prize and bonus. Conversely, the incentive option prize produced the highest R.F of $14.66 \%$ for food waste. In the service zones, the highest dry recyclables R.F was produced in the low-income service zone (73.86\%). The least dry recyclables R.F (39.23\%) was generated in the high-income door-to-door service zone. Overall, dry recyclables had the highest R.F of $59.97 \%$ while that of food waste registered R.F of $10.03 \%$. The result of the recovery factors (R.F) estimation for the target materials in the recycling scheme observed a higher R.F for dry recyclables than food waste.

Table 2. Percentage recovery rate of waste materials per incentives and service zones.

\begin{tabular}{ccccccc}
\hline & \multicolumn{5}{c}{ \% Recovery Factor of Recyclables and Food Waste Per Incentive Options } \\
\hline Incentive options & \multicolumn{2}{c}{ Waste receptacles } & \multicolumn{2}{c}{ Prize } & \multicolumn{2}{c}{ Bonus } \\
\hline Service zone & Dry recyclables & Food waste & Dry recyclables & Food waste & Dry recyclables & Food waste \\
\hline HI DtD & 23.45 & 28.31 & 18.07 & 29.08 & 27.95 & 9.05 \\
MI DtD & 2.72 & 2.87 & 11.58 & 21.05 & 32.61 & 1.17 \\
MIC & 28.33 & 24.26 & 36.28 & 10.02 & 10.42 & 19.87 \\
LIC & 29.62 & 1.97 & 22.17 & 1.97 & 31.31 & 16.93 \\
Overall R. F. & 29.92 & 13.091 & 23.18 & 14.66 & 27.21 & 12.61 \\
\hline \multicolumn{7}{c}{ \% Recovery factor of recyclables and food waste per service zone } \\
\hline Waste type & HI DtD & MI DtD & MIC & LIC & Overall \% R.F \\
Dry recyclables & 39.25 & 40.96 & 53.02615 & 73.86 & 53.97 \\
Food waste & 20.55 & 5.368 & 24.68 & 2.00 & 10.03 \\
\hline
\end{tabular}

Waste receptacles as an incentive option produced the highest recovery factor for dry recyclables in the scheme, as well as in the low-income service zone, while it produced the highest food waste 
recovery in the high-income service zone. It can be deduced from the findings that factors such as well-designed and implemented rewards or incentive schemes are stronger influential factors on households' recycling behavior and waste material resources recovery. It can be inferred from the findings from the study that financial incentives are crucial towards leveraging existing behavioral patterns towards recycling of municipal solid waste in different service zones. The combination of the mentioned aspects and consideration of local conditions could be a solid basis to develop high-performing source separation and recycling schemes.

\subsection{Effect of Incentives, Collection Modes, and Service Zone on Waste Materials Quantities}

The multivariate analysis of variance (MANOVA) on waste quantities against collection mode, incentive options, as well as service zones, showed variations in food waste and dry recyclables quantities recovered across incentives and service zones. The results in Table 3 show a statistically significant difference $(p<0.05)$ in waste materials quantities retrieved under incentive options and service zones. It was found out that there were statistically significant differences in waste quantities across incentives and service zones and the interaction of the two. However, there was no statistically significant difference in waste quantities across collection modes as indicated by the probability values of all four (4) statistical tests. The interaction effect indicates that there was a statistically significant difference in waste quantities across service zones and the incentive options (bonus, price, and waste receptacle). Whereas the probability values for service zones and the interaction between service zones and incentive options are significant at $1 \%$, those for only incentive options was significant at $5 \%$. The multivariate regression (mvreg) estimates showed F-value of 6.37 significant at $1 \%$ with $R^{2}$ of 34.66 which indicates that about $35 \%$ of variations in dry recyclables is explained by the joint contribution of incentives and collection modes. Likewise, the F-value registered for food waste was 7.14, significant at $1 \%$ with $\mathrm{R}^{2}$ of 37.32 , indicating that about $37 \%$ of the variation in the food waste quantities can be attributed to incentives or collection modes. It was observed that the effects of incentives on dry recyclables quantities in the low-income zone were positive at $1 \%$ with a coefficient of 5270.86 compared to high-income door-to-door service zone. The incentive option that contributes to the variations in dry recyclables was prize, which showed a positive interaction effect on dry recyclables quantities at $10 \%$ in the high-income door-to-door zone and middle-income door-to-door zone at $1 \%$.

In terms of food waste, the interaction of prize and middle-income door-to-door zone and the interactions of prize in the low-income communal zone and that of waste receptacles and low-income communal zone contributed to the variations in the food waste quantities. Prize had a positive statistically significant effect on food waste quantities at $1 \%$, with a coefficient of 1279.72 . This means that prize as an incentive option produced $1279.72 \mathrm{~g}$ more food waste compared to bonus as an incentive option. However, the high-income door-to-door service zone had $1159.78 \mathrm{~g}$ more food waste compared to the middle-income door-to-door zone and this was significant at $5 \%$. The interaction of prize and low-income communal zone recorded less food waste $(-2966.67 \mathrm{~g})$ compared to price in the high-income door-to-door zone; this was significant at $1 \%$. The interaction between waste receptacles and the low-income communal zone was also found to negatively affect food waste quantities at $5 \%$, with a coefficient of 1639.98 . The study revealed that incentives have significant effects on waste materials quantities recovered per service zones. This implies that the quantity of waste materials that may be recovered in a recycling scheme across different service zones depends on the incentive type employed in the scheme. 
Table 3. Differences in waste material quantities across incentives, collection modes, and service zones.

\begin{tabular}{cccccccc}
\hline Source & \multicolumn{2}{c}{ Statistics } & DF & F (df1) & F (df2) & F & Prob > F \\
\hline \multirow{3}{*}{ Model } & W & 0.3866 & 11 & 22.0 & 262.0 & 7.24 & 0.0000 \\
& $\mathrm{P}$ & 0.7446 & & 22.0 & 264.0 & 7.12 & 0.0000 \\
& $\mathrm{~L}$ & 1.2473 & & 22.0 & 260.0 & 7.37 & 0.0000 \\
& $\mathrm{R}$ & 0.8461 & & 11.0 & 132.0 & 10.15 & 0.0000 \\
\hline Residual & & & 132 & & & & \\
\hline \multirow{3}{*}{ Collection modes } & $\mathrm{W}$ & 0.9864 & 1 & 2.0 & 131.0 & 0.90 & 0.4088 \\
& $\mathrm{P}$ & 0.0136 & & 2.0 & 131.0 & 0.90 & 0.4088 \\
& $\mathrm{~L}$ & 0.0137 & & 2.0 & 131.0 & 0.90 & 0.4088 \\
& $\mathrm{R}$ & 0.0137 & & 2.0 & 131.0 & 0.90 & 0.4088 \\
\hline \multirow{3}{*}{ Incentive options } & $\mathrm{W}$ & 0.9236 & 2 & 4.0 & 262.0 & 2.66 & 0.0335 \\
& $\mathrm{P}$ & 0.0769 & & 4.0 & 264.0 & 2.64 & 0.0343 \\
& $\mathrm{~L}$ & 0.0822 & & 4.0 & 260.0 & 2.67 & 0.0326 \\
& $\mathrm{R}$ & 0.0751 & & 2.0 & 132.0 & 4.96 & 0.0084 \\
\hline Service zones & $\mathrm{W}$ & 0.6392 & 2 & 4.0 & 262.0 & 16.43 & 0.0000 \\
& $\mathrm{P}$ & 0.3693 & & 4.0 & 264.0 & 14.95 & 0.0000 \\
& $\mathrm{~L}$ & 0.5511 & & 4.0 & 260.0 & 17.91 & 0.0000 \\
& $\mathrm{R}$ & 0.5257 & & 2.0 & 132.0 & 34.70 & 0.0000 \\
\hline \multirow{3}{*}{ Service zones and incentive options } & $\mathrm{W}$ & 0.7328 & 6 & 12.0 & 262.0 & 3.67 & 0.0000 \\
& $\mathrm{P}$ & 0.2824 & & 12.0 & 264.0 & 3.62 & 0.0001 \\
& $\mathrm{~L}$ & 0.3437 & & 12.0 & 260.0 & 3.72 & 0.0000 \\
& $\mathrm{R}$ & 0.2652 & & 6.0 & 132.0 & 5.83 & 0.0000 \\
\hline Residual & & & 132 & & & & \\
\hline Number of observations & & & 143 & & & & \\
\hline
\end{tabular}

$\mathrm{W}=$ Wilk's lambda; $\mathrm{P}$ = Pillai's trace; $\mathrm{L}$ = Lawley-Hotelling trace; $\mathrm{R}$ = Roy's largest root.

\subsection{Waste Materials Separation Efficiency and Households Set-Out Rate per Incentive Options}

The study assessed the ability of participating households to properly sort the waste components into their designated bags. The result in Table 4 shows mean variations in separation efficiencies for targeted waste types and households' set-out for those materials. The highest separation efficiency (S.E.) for dry recyclables and food waste was registered by the incentive option of waste receptacles, thus, $92.87 \%$ and $45.02 \%$, respectively, followed by bonus with S.E. of $82.31 \%$ for dry recyclables and $41.42 \%$ S.E. for food waste. Waste receptacles registered the highest set-out rate $(69.31 \%)$ while that of food waste was registered by prize (83.29\%). The high waste material separation efficiency can be attributed to the fact that partaking households were available and were educated on each collection day on the sorting procedures. This emphasizes the effect more education could have on improving source separation programmes. From the result, it can be observed that set-out rate was high for food waste than dry recyclables for two incentive options, namely, bonus and prize. It was observed that waste receptacles registered a higher set-out for dry recyclables than food waste. However, separation efficiency was higher for dry recyclables for all the incentive options than food waste. The study indicates a higher \% separation efficiency for dry recyclable waste materials but lower $\%$ household set-out rate. It was observed from the study that, though the household set-out rate was high for food waste, it registered a lower \% separation efficiency compared to dry recyclables. 
Table 4. Average separation efficiency (S.E.) and set-out for separated materials per incentive options.

\begin{tabular}{ccccc}
\hline Incentive Options & Variable & Mean \pm SD & Min. & Max. \\
\hline Bonus & S.E. for food waste & $41.42 \pm 35.10$ & 0 & 100 \\
& S.E. for dry recyclables & $82.31 \pm 26.48$ & 0 & 100 \\
& Set-out for food waste & $51.53 \pm 20.92$ & 10 & 90 \\
& Set-out for dry recyclables & $40.35 \pm 25.33$ & 0 & 100 \\
Prize & S.E. for food waste & $36.72 \pm 30.39$ & 0 & 95.2 \\
& S.E. for dry recyclables & $65.77 \pm 27.06$ & 0 & 100 \\
& Set-out for food waste & $83.29 \pm 137.60$ & 3.33 & 100 \\
Waste receptacles & Set-out for dry recyclables & $59.44 \pm 26.63$ & 0 & 100 \\
& S.E. for food waste & $45.02 \pm 45.20$ & 0 & 100 \\
& S.E. for dry recyclables & $92.87 \pm 8.81$ & 59.94 & 100 \\
& Set-out for food waste & $61.39 \pm 33.66$ & 3.33 & 100 \\
& Set-out for dry recyclables & $69.31 \pm 34.16$ & 10 & 100 \\
\hline
\end{tabular}

S.E. - FW is separation efficiency for food waste; S.E.-DR is separation efficiency for dry recyclables, set-out-FW is set-out for food waste; set- out-DR is set- out for dry recyclables.

The mean \% separation efficiency for dry recyclables was $49.65 \%$ higher than that of food waste while mean $\%$ of the set-out for food waste was $36.97 \%$ higher than that of dry recyclables materials. These findings are similar to that reported by [60] in China which reported a higher separation rate for dry waste than food waste. The result is also consistent with [6] study which recorded differences in separation efficiencies for some recyclable materials across three districts in New York. The findings of this study are also similar to a study in Sweden outlined in [61] which recorded a higher sorted ratio for dry recyclables in municipalities with extended curbside collection but contradicts the previous study by [14] in Ghana who reported highest separation efficiency in the organic component followed by other wastes and the least separation efficiency for plastic components.

\subsection{Effect of Incentives, Collection Modes and Service Zones on Waste Materials Separation Efficiency}

The multivariate analysis of variance conducted on set-out and separation efficiency for waste materials against incentive options and service zones observed statistically significant differences in set-out and separation efficiency for waste materials among incentive options, service zones, and the interaction of the two $(p<0.05)$ (Table 5). It was observed that there were statistically significant differences $p<0.05$ in separation efficiency of waste materials and household set-out rate under the various service zones and incentive options (bonus, price, and waste receptacle). The interaction effect also indicated statistically significant $(p<0.01)$ effects of incentive options (bonus, prize, and waste receptacle) and service zones on waste material separation efficiency and households set-out rates. The import is that incentives do not only affect the set-out rate and separation efficiency of waste materials resources but also distinguish the difference that may occur in set-out rate and separation efficiency for target materials in a recycling scheme across different MSW service zones. 
Table 5. Differences in separation efficiency of dry recyclables and food waste across incentives, collection modes, and service zones.

\begin{tabular}{|c|c|c|c|c|c|c|c|}
\hline Source & \multicolumn{2}{|c|}{ Statistics } & DF & F (df1) & $F(d f 2)$ & F & Prob $>$ F \\
\hline \multirow{4}{*}{ Model } & W & 0.1558 & 11 & 22.0 & 262.0 & 18.26 & 0.0000 \\
\hline & $\mathrm{P}$ & 1.1187 & & 22.0 & 264.0 & 15.23 & 0.0000 \\
\hline & $\mathrm{L}$ & 3.6572 & & 22.0 & 260.0 & 21.61 & 0.0000 \\
\hline & $\mathrm{R}$ & 3.0862 & & 11.0 & 132.0 & 37.03 & 0.0000 \\
\hline Residual & & & 132 & & & & \\
\hline \multirow{4}{*}{ Collection modes } & W & 0.6189 & 1 & 2.0 & 131.0 & 40.33 & 0.0000 \\
\hline & $\mathrm{P}$ & 0.3811 & & 2.0 & 131.0 & 40.33 & 0.0000 \\
\hline & $\mathrm{L}$ & 0.6158 & & 2.0 & 131.0 & 40.33 & 0.0000 \\
\hline & $\mathrm{R}$ & 0.6158 & & 2.0 & 131.0 & 40.33 & 0.0000 \\
\hline \multirow{4}{*}{ Incentive options } & W & 0.8824 & 2 & 4.0 & 262.0 & 4.23 & 0.0025 \\
\hline & $\mathrm{P}$ & 0.1198 & & 4.0 & 264.0 & 4.20 & 0.0026 \\
\hline & $\mathrm{L}$ & 0.1307 & & 4.0 & 260.0 & 4.25 & 0.0024 \\
\hline & $\mathrm{R}$ & 0.1071 & & 2.0 & 132.0 & 7.07 & 0.0012 \\
\hline \multirow{4}{*}{ Service zones } & W & 0.3858 & 2 & 4.0 & 262.0 & 39.95 & 0.0000 \\
\hline & $\mathrm{P}$ & 0.6302 & & 4.0 & 264.0 & 30.36 & 0.0000 \\
\hline & $\mathrm{L}$ & 1.5506 & & 4.0 & 260.0 & 50.39 & 0.0000 \\
\hline & $\mathrm{R}$ & 1.5234 & & 2.0 & 132.0 & 100.54 & 0.0000 \\
\hline \multirow{4}{*}{ Service zones \& incentive options } & $\mathrm{W}$ & 0.3261 & 6 & 12.0 & 262.0 & 16.40 & 0.0000 \\
\hline & $\mathrm{P}$ & 0.7896 & & 12.0 & 264.0 & 14.35 & 0.0000 \\
\hline & $\mathrm{L}$ & 1.7124 & & 12.0 & 260.0 & 18.55 & 0.0000 \\
\hline & $\mathrm{R}$ & 1.4713 & & 6.0 & 132.0 & 32.37 & 0.0000 \\
\hline \multicolumn{3}{|l|}{ Residual } & 132 & & & & \\
\hline \multicolumn{3}{|c|}{ Total } & 143 & & & & \\
\hline \multicolumn{3}{|c|}{ Number of observations } & 144 & & & & \\
\hline
\end{tabular}

\section{Conclusions}

This study provided important information on setting priorities in incentive options to employ to support efficient source separation and recycling schemes. There were variations in the quantity of waste materials retrieved under various incentive options and service zones. Prize as an incentive option registered the largest quantities of dry recyclables and food waste across the service zones. Provision of waste receptacles yielded high quantities of dry recyclables per household while prize yielded the highest quantity of food waste per household for the study period. The study found that provision of prize in addition to a waste storage facility as incentive produced more waste materials compared to bonus and sole provision of waste receptacles. Therefore, source separation and recycling scheme that focuses more on the provision of prize in addition to waste storage facilities as a reward scheme may be more successful in yielding more targeted waste materials resources in the service zones.

As per the study, separation efficiency (\% S.E) for dry recyclables was higher across all incentive options than food waste except for prize in the high-income door-to-door service zone. It was observed that $\%$ S.E was low in the middle-income door-to-door zone for dry recyclables while $\%$ S.E for food waste was low in the low-income communal service zone. There is, therefore, a need to intensify education in future source separation/recycling scheme in these service zones for effective MSW separation at source.

The multivariate analysis of variance on the waste materials quantities against incentive schemes indicated significant differences in waste material quantities across incentives and service zones. Similarly, there were significant differences in set-out rate and separation efficiency of waste materials across incentives and the service zones. The multivariate regression analysis revealed significant effects 
of incentives on waste materials quantities produced across the service zones. The study showed that provision of incentives is an important factor to consider in a recycling scheme for effective waste materials resources recovery in different service zones. However, the resulting output(waste material resources) from the incentives may depend on the type of incentive provided and the service zone under consideration and more importantly, the incentives must be specific to the targeted material and the service zone under consideration. The study highlights the incentive types and service zones to focus on in a recycling scheme to achieve high material recovery rates, and contributes to the existing literature on how incentives influence waste materials recovery in different service zones.

Author Contributions: S.O.K., E.A.D., and W.A. contributed to the study conception and design, literature review and interpretation. S.O.K., W.A., E.A.D., and M.A.D.R. participated in the drafting of manuscript and preparation of final version. All authors have read and agreed to the published version of the manuscript.

Funding: The study was funded by the Regional Water and Environmental Sanitation Centre Kumasi (RWESCK) at the Kwame Nkrumah University of Science and Technology (KNUST), Kumasi with funding from the Ghana Government through the World Bank under the Africa Centres of Excellence project.

Acknowledgments: The authors are grateful to the Regional Water and Environmental Sanitation Centre Kumasi (RWESCK) at the Kwame Nkrumah University of Science and Technology (KNUST), Kumasi with funding from the Ghana Government through the World Bank under the Africa Centres of Excellence project for funding this research and would like to state that the views expressed in this paper do not reflect those of the World Bank, Ghana Government and RWESCK, KNUST.

Conflicts of Interest: The authors of this article have no competing interests.

\section{References}

1. Zen, I.S.; Noor, Z.Z.; Yusuf, R.O. The profiles of household solid waste recyclers and non-recyclers in Kuala Lumpur, Malaysia. Habitat Int. 2014, 42, 83-89. [CrossRef]

2. Pichtel, J. Waste Management Practices; Municipal, Hazardous, and Industrial, 2nd ed.; CRC Press: Boca Raton, FL, USA; Taylor and Francis Group: New York, NY, USA, 2014.

3. Kaza, S.; Yao, L.; Bhada-Tata, P.; Van Woerden, F. What a Waste 2.0: A Global Snapshot of Solid Waste Management to 2050; The World Bank: Washington, DC, USA, 2018. [CrossRef]

4. Zhang, L.; Yuan, Z.; Bi, J.; Huang, L. Estimating future generation of obsolete household appliances in China. Waste Manag. Res. 2012, 30, 1160-1168. [CrossRef] [PubMed]

5. Bennagen, M.E.C.; Nepomuceno, G.; Covar, R. Solid Waste Segregation and Recycling. In Metro Manila: Household Attitudes and Behavior. EEPSEA Research Reports; Economy and Environment Program for Southeast Asia (EEPSEA): Tanglin, Singapore, 2002; Available online: http://nswai.com/docs/Solid\%20Waste\% 20Segregation\%20and\%20Recycling\%20in\%20Metro\%20Manila.pdf (accessed on 10 January 2020).

6. Aphale, O.; Thyberg, K.L.; Tonjes, D.J. Differences in waste generation, waste composition, and source separation across three waste districts in a New York suburb. Resour. Conserv. Recycl. 2015, 99, 19-28. [CrossRef]

7. Couth, R.; Trois, C. Carbon emissions reduction strategies in Africa from improved waste management: A review. Waste Manag. 2010, 30, 2336-2346. [CrossRef] [PubMed]

8. Tinmaz, E.; Demir, I. Research on solid waste management system: To improve existing situation in Corlu Town of Turkey. Waste Manag. 2006, 26, 307-314. [CrossRef] [PubMed]

9. Asare, W.; Andrews, A.; Asare, R. Households Solid Waste Generation and Disposal in Some Selected Communities in Ejisu-Juaben Municipality, Ghana. J. Sci. Res. Rep. 2015, 6, 371-382. [CrossRef]

10. Asian Development Bank. Materials Recovery Facility Tool Kit. Mandaluyong, Philippines. 2013, pp. 1-5. ISBNSS: 978-92-9254-017-3. 2013. Available online: https:/www.adb.org/sites/default/files/publication/30220/ materials-recovery-facility-tool-kit.pdf (accessed on 12 June 2020).

11. Parfitt, J.P.; Flowerdew, R. Methodological problems in the generation of household waste statistics. Appl. Geogr. 1997, 17, 231-244. [CrossRef]

12. Timlett, R.; Williams, I. Public participation and recycling performance in England: A comparison of tools for behaviour change. Resour. Conserv. Recycl. 2008, 52, 622-634. [CrossRef]

13. Hornik, J.; Cherian, J.; Madansky, M.; Narayana, C. Determinants of recycling behavior: A synthesis of research results. J. Socio-Econ. 1995, 24, 105-127. [CrossRef] 
14. Oduro-Kwarteng, S.; Anarfi, K.P.; Essandoh, H.M. Source separation and recycling potential of municipal solid waste in Ghana. Manag. Environ. Qual. Int. J. 2016, 27, 210-226. [CrossRef]

15. Amini, F.; Ahmad, J.; Ambali, A.R. The Influence of Reward and Penalty on Households' Recycling Intention. APCBEE Procedia 2014, 10, 187-192. [CrossRef]

16. Clark, J.; Shah, N. Waste or Resource? Stimulating a Bio Economy. Science and Technology Select Committee: 3rd Report of Session 2013-14; House of Lords: London, UK, 2014; Available online: https://publications. parliament.uk/pa/ld201314/ldselect/ldsctech/141/141.pdf (accessed on 12 March 2020).

17. Hage, O.; Söderholm, P.; Berglund, C. Norms and economic motivation in household recycling: Empirical evidence from Sweden. Resour. Conserv. Recycl. 2009, 53, 155-165. [CrossRef]

18. Nyborg, K.; Howarth, R.B.; Brekke, K.A. Green consumers and public policy: On socially contingent moral motivation. Resour. Energy Econ. 2006, 28, 351-366. [CrossRef]

19. Rousta, K.; Zisen, L.; Hellwig, C. Household Waste Sorting Participation in Developing Countries-A Meta-Analysis. Recycling 2020, 5, 6. [CrossRef]

20. Vassanadumrongdee, S.; Kittipongvises, S. Factors influencing source separation intention and willingness to pay for improving waste management in Bangkok, Thailand. Sustain. Environ. Res. 2018, 28, 90-99. [CrossRef]

21. Xu, L.; Ling, M.; Wu, Y. Economic incentive and social influence to overcome household waste separation dilemma: A field intervention study. Waste Manag. 2018, 77, 522-531. [CrossRef]

22. Xu, L.; Ling, M.; Lu, Y.; Shen, M. External influences on forming residents' waste separation behaviour: Evidence from households in Hangzhou, China. Habitat Int. 2017, 63, 21-33. [CrossRef]

23. Xu, W.; Zhou, C.; Lan, Y.; Jin, J.; Cao, A. An incentive-based source separation model for sustainable municipal solid waste management in China. Waste Manag. Res. 2015, 33, 469-476. [CrossRef]

24. Batool, S.A.; Chaudhry, M.N.; Majeed, K. Economic potential of recycling business in Lahore, Pakistan. Waste Manag. 2008, 28, 294-298. [CrossRef]

25. Suttibak, S.; Nitivattananon, V. Assessment of factors influencing the performance of solid waste recycling programs. Resour. Conserv. Recycl. 2008, 53, 45-56. [CrossRef]

26. Gollwitzer, P.M. Implementation intentions: Strong effects of simple plans. Am. Psychol. 1999, 54, 493-503. [CrossRef]

27. Guagnano, G.A.; Stern, P.C.; Dietz, T. Influences on attitude-behavior relationships a natural experiment with curbside recycling. Environ. Behav. 1995, 27, 699-718. [CrossRef]

28. Matter, A.; Dietschi, M.; Zurbrügg, C. Improving the informal recycling sector through segregation of waste in the household.The case of Dhaka Bangladesh. Habitat Int. 2013, 38, 150-156. [CrossRef]

29. Miezah, K.; Obiri-Danso, K.; Kádár, Z.; Fei-Baffoe, B.; Mensah, M.Y. Municipal solid waste characterization and quantification as a measure towards effective waste management in Ghana. Waste Manag. 2015, 46, 15-27. [CrossRef]

30. Owusu, V.; Adjei-Addo, E.; Sundberg, C. Do economic incentives affect attitudes to solid waste source separation? Evidence from Ghana. Resour. Conserv. Recycl. 2013, 78, 115-123. [CrossRef]

31. Shaw, P.J.; Lyas, J.K.; Hudson, M.D. Quantitative analysis of recyclable materials composition: Tools to support decision making in kerbside recycling. Resour. Conserv. Recycl. 2006, 48, 263-279. [CrossRef]

32. Addo, E.A. Economic Analysis of Household Source Separation of Solid Waste: The Case of Kumasi Metropolis of the Ashanti Region of Ghana. Master's Thesis, Kwame Nkrumah University of Science and Technology, Ashanti, Ghana, 2009.

33. Tchobanoglous, G.; Theisen, H.; Vigil, S. Integrated Solid Waste Management: Engineering Principles and Management Issues; McGraw Hill: New York, NY, USA, 1993; pp. 17-52.

34. AEA. Technology Environment. Evaluation of the Household Waste Incentives Pilot Scheme. Final Report to Defra (Waste Strategy Division), Report Nr. AEAT/ED51352/Issue1.2006. Available online: http://sciencesearch.defra.gov.uk/Default.aspx?Menu=Menu\&Module=More\&Location= None\&Completed=0\&ProjectID=15402 (accessed on 20 February 2020).

35. Harder, M.K.; Woodard, R. Systematic studies of shop and leisure voucher incentives for household recycling. Resour. Conserv. Recycl. 2007, 51, 732-753. [CrossRef]

36. Elange, F.; Brückner, C.; Kröger, B.; Beller, J.; Eggert, F. Wasting ways: Perceived distance to the recycling facilities predicts pro-environmental behavior. Resour. Conserv. Recycl. 2014, 92, 246-254. [CrossRef]

37. Asase Mizpah, A.D. Solid Waste Separation at Source: A Case Study of the Kumasi Metropolitan Area. Ph.D. Thesis, Kwame Nkrumah University of Science and Technology, Ashanti, Ghana, 2011. 
38. Zen, I.S.; Subramaniam, D.; Sulaiman, H.; Saleh, A.L.; Omar, W.; Salim, M.R. Institutionalize waste minimization governance towards campus sustainability: A case study of Green Office initiatives in Universiti Teknologi Malaysia. J. Clean. Prod. 2016, 135, 1407-1422. [CrossRef]

39. Tchobanoglous, G.; Kreith, F. (Eds.) Handbook of Solid Waste Management; McGraw-Hill: New York, NY, USA, 2002.

40. Ghana Statistical Service. Available online: http://www2.statsghana.gov.gh/docfiles/publications/Labour_ Force/LFS\%20REPORT_fianl_21-3-17.pdf (accessed on 7 August 2019).

41. Cochran, W. Survey Sampling; John Wiley: Hoboken, NJ, USA, 1977.

42. Gómez, G.; Meneses, M.; Ballinas, L.; Castells, F. Characterization of urban solid waste in Chihuahua, Mexico. Waste Manag. 2008, 28, 2465-2471. [CrossRef]

43. Gallardo, A.; Bovea, M.D.; Colomer, F.J.; Prades, M. Analysis of collection systems for sorted household waste in Spain. Waste Manag. 2012, 32, 1623-1633. [CrossRef] [PubMed]

44. ASTM. International Standard Test Method for Determination of the Composition of Unprocessed Municipal Solid Waste, ASTM D5231-92, American Society for Testing and Materials. 2003. Available online: https://www.astm.org/DATABASE.CART/HISTORICAL/D5231-92R03.htm (accessed on 2 October 2020).

45. Chandrappa, R.; Das, D.B. Solid Waste Management: Principles and Practice; Förstner, U., Rulkens, W.H., Salomons, W., Eds.; Environmental Science; Springer: Heidelberg, Germany, 2012. [CrossRef]

46. Alias, S.F.; Manaf, L.A.; Abdullah, S.J.H.; Onn, M.H.N. Solid waste generation and composition at water villages in Sabah, Malaysia. Pol. J. Environ. Stud. 2014, 23, 1475-1481.

47. Tränkler, J.; Visvanathan, C.; Kuruparan, P.; Tubtimthai, O. Influence of tropical seasonal variations on landfill leachate characteristics—Results from lysimeter studies. Waste Manag. 2005, 25, 1013-1020. [CrossRef] [PubMed]

48. Ezeah, C.; Roberts, C.L. Analysis of barriers and success factors affecting the adoption of sustainable management of municipal solid waste in Nigeria. J. Environ. Manag. 2012, 103, 9-14. [CrossRef] [PubMed]

49. Yang, L.; Li, Z.-S.; Fu, H.-Z. Model of municipal solid waste source separation activity: A case study of Beijing. J. Air Waste Manag. Assoc. 2011, 61, 157-163. [CrossRef] [PubMed]

50. Abu Samah, M.A.; Hamid, K.B.A.; Ishak, M.Y. Analysis of Municipal Solid Waste Generation and Composition at Administrative Building Café in Universiti Putra Malaysia: A Case Study. Pol. J. Environ. Stud. 2015, 24, 1969-1982. [CrossRef]

51. Dvorsak, S.; Varga, J.; Stavrakakis, G.; Moustakas, K.; Loizidou, M.; Inglezakis, V.; Venetis, C.; Movila, L.; Ardeleanu, N.; Ilieva, L. Sampling and Analysis of Solid Municipal Waste in Balkan Region: The First Results and Their Significance. National Technical University of Athens, Athens, Greece. Available online: https://www.iswa.org/uploads/tx_iswaknowledgebase/Moustakas.pdf (accessed on 25 May 2020).

52. Metin, E.; Eröztürk, A.; Neyim, C. Solid waste management practices and review of recovery and recycling operations in Turkey. Waste Manag. 2003, 23, 425-432. [CrossRef]

53. Mohee, R. Assessing the recovery potential of solid waste in Mauritius. Resour. Conserv. Recycl. 2002, 36, 33-43. [CrossRef]

54. Al-Khatib, I.A.; Monou, M.; Abu Zahra, A.S.F.; Shaheen, H.Q.; Kassinos, D. Solid waste characterization, quantification and management practices in developing countries. A case study: Nablus district-Palestine. J. Environ. Manag. 2010, 91, 1131-1138. [CrossRef]

55. Abota, C.A. Recycling of Plastics Waste in Ghana; A Way to Reduce Environmental Problems/Pollutions. Degree Thesis, Plastic Technology, ARCADA. 2012. Available online: https://core.ac.uk/download/pdf/ 38059012.pdf (accessed on 10 March 2020).

56. Maki, A.; Burns, R.J.; Ha, L.; Rothman, A.J. Paying people to protect the environment: A meta-analysis of financial incentive interventions to promote proenvironmental behaviors. J. Environ. Psychol. 2016, 47, 242-255. [CrossRef]

57. Boonrod, K.; Towprayoon, S.; Bonnet, S.; Tripetchkul, S. Enhancing organic waste separation at the source behavior: A case study of the application of motivation mechanisms in communities in Thailand. Resour. Conserv. Recycl. 2015, 95, 77-90. [CrossRef]

58. Hoornweg, D.; Bhada-Tata, P. What a Waste: A global Review of Solid Waste Management, Urban Development Series Knowledge Papers; The World Bank: Washington, DC, USA, 2012.

59. Strategy Unit. Waste not, Want not-A Strategy for Tackling the Waste Problem in England. 2002. Available online: http://mie.esab.upc.es/ms/informacio/sostenibilitat/Wastes\%20England.pdf (accessed on 21 April 2016). 
60. Zhuang, Y.; Wu, S.-W.; Wang, Y.-L.; Wu, W.; Chen, Y.-X. Source separation of household waste: A case study in China. Waste Manag. 2008, 28, 2022-2030. [CrossRef] [PubMed]

61. Dahlén, L.; Vukicevic, S.; Meijer, J.-E.; Lagerkvist, A. Comparison of different collection systems for sorted household waste in Sweden. Waste Manag. 2007, 27, 1298-1305. [CrossRef] [PubMed]

Publisher's Note: MDPI stays neutral with regard to jurisdictional claims in published maps and institutional affiliations.

(C) 2020 by the authors. Licensee MDPI, Basel, Switzerland. This article is an open access article distributed under the terms and conditions of the Creative Commons Attribution (CC BY) license (http://creativecommons.org/licenses/by/4.0/). 